\title{
Adult-onset variant ataxia-telangiectasia diagnosed by exome and cDNA sequencing
}

Martin Krenn, MD, Ivan Milenkovic, MD, PhD, Gertrud Eckstein, PhD, Fritz Zimprich, MD, PhD, Thomas Meitinger, MD, Thomas Foki, MD, and Matias Wagner, MD

Neurol Genet 2019;5:e346. doi:10.1212/NXG.0000000000000346

Ataxia-telangiectasia (A-T) is an autosomal recessive disorder caused by mutations in ATM, encoding a serine-threonine protein kinase that is crucially involved in DNA repair mechanisms. Clinical features include cerebellar degeneration, telangiectasia, immunodeficiency, and an increased risk of malignancies. ${ }^{1}$ The classic form of A-T is characterized by infantile, rapidly progressing neurodegeneration and can be differentiated from variant $\mathrm{A}-\mathrm{T}$ with a comparably milder disease course. ${ }^{2,3}$ However, only a tiny fraction of patients first present with symptoms in adulthood. ${ }^{4}$ The broad phenotypic spectrum of A-T now becomes gradually disentangled owing to the increased availability of comprehensive genetic testing. ${ }^{5}$

Here, we point out possible diagnostic pitfalls with an example of an adult-onset A-T, in which exome sequencing (ES) complemented by transcriptome analysis, complementary deoxyribonucleotide acid (cDNA) sequencing, and family genotyping eventually led to the definite genetic diagnosis $\mathrm{A}-\mathrm{T}$.

\section{Clinical and genetic findings}

Our female index patient (currently aged 45 years) first developed gait instability at age 34 years. Furthermore, dizziness and affective lability were reported. At this time, a neurologic examination was unremarkable and did not reveal any signs of cerebellar dysfunction.

Symptoms were slowly progressive over the following 10 years, and she first presented at our department at age 43 years. Clinical examination revealed bilateral ataxia with wide-based gait, downbeat nystagmus, mild dysarthria, and brisk reflexes. Brain MRI showed moderate to severe bilateral cerebellar atrophy (figure, A). Electrooculography confirmed a downbeat nystagmus, saccadic pursuit, and slowed and hypometric saccades with absent vestibulo-ocular reflex suppression indicating cerebellar dysfunction (pathologic eye movements are shown in video 1). Dizziness was most pronounced during head-turning movements.

Given a positive family history with the patient's elder sister even being more severely affected with ataxia (starting at age 28 years), a genetic etiology was suspected. Subsequently performed ES revealed 1 pathogenic nonsense variant $(c .6205 \mathrm{C}>\mathrm{T}$, p.Gln2069*) and 1 intronic variant $($ c. $1235+3 A>G)$ of uncertain significance (VUS) in ATM as classified by the American College of Medical Genetics and Genomics criteria. ${ }^{6}$ The nonsense variant was absent from Genome Aggregation Database and our in-house database comprising more than 16,500 exome data sets, and the intronic variant, which is located in proximity to exon 9, was present twice in each database.

\author{
Correspondence \\ Dr. Wagner \\ Matias.Wagner@mri.tum.de
}

MORE ONLINE

๑ Video 

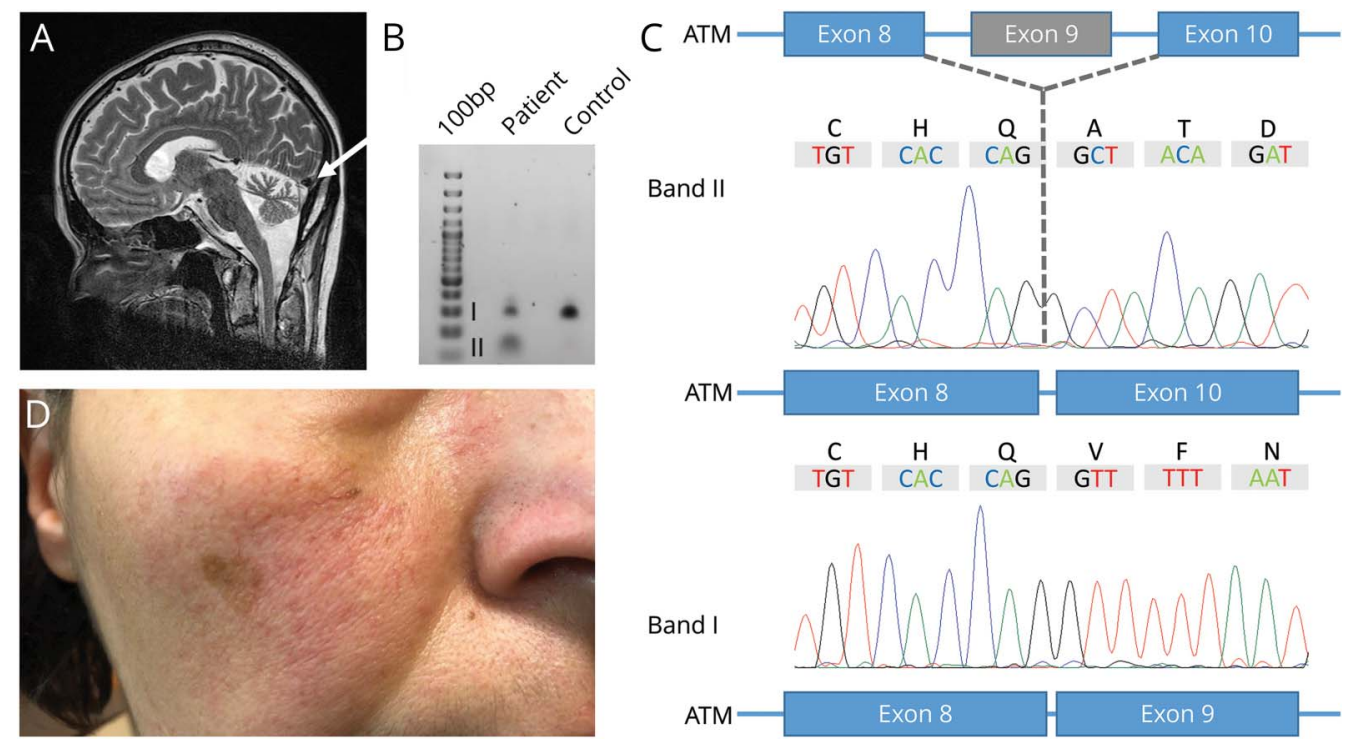

(A) Brain MRI. Sagittal T2-weighted MRI of the reported index patient demonstrating moderate to severe cerebellar atrophy (white arrow). (B) Gel electrophoresis of PCR-amplified ATM CDNA showing 2 distinct splice variants as a result of the mutation c.1235+3A>G. (C) Subsequent Sanger sequencing of dissected bands further characterized the misspliced transcript with skipping of exon 9 (band II). (D) Photograph of the index patient's right cheek showing telangiectasia.

To further delineate the pathogenicity of the intronic variant, we sought to investigate a potential splicing defect using polyA-enriched RNA sequencing from whole blood using PAXgene Blood RNA tubes (Qiagen, Hilden, Germany). ${ }^{7}$ With an mRNA length of 13,147 nucleotides and due to the location of exon 9 toward the $5^{\prime}$ end of the ATM transcript, RNA sequencing coverage was insufficient to evaluate a splicing effect. Subsequently, we specifically targeted the $5^{\prime}$ end with a primer binding to exon 25 of ATM (3'-GAATGGATTAGAACCTCACC-5') for reverse transcription. With primers binding to exons 8 and 10 (sequences available upon request), we could demonstrate skipping of exon 9 leading to a frameshift and the premature termination of protein translation (p.Val356Alafs* 17 ; figure, C and D).

The 2 variants segregated with the disease phenotype within the family. Once a genetic diagnosis of A-T had been established, subtle but evident telangiectasia of the conjunctiva, face (figure, B), and chest was clinically confirmed by a dermatologist. Blood levels of alpha-fetoprotein were within the normal range. There has been no evidence for malignancy or immunodeficiency. Currently, the described index patient and her affected sister are still ambulatory despite gait ataxia with a marked tendency to fall.

\section{Discussion}

Variant A-T represents a subgroup of A-T characterized by a milder disease course compared with the classic form. Despite slower disease progression, the vast majority of patients first manifest in early childhood, and adult onset remains a rare phenomenon. ${ }^{4}$ It has been suggested that mainly the mutation type predicts the clinical course with missense variants leading to a milder phenotype but an increased risk of cancer. $^{5}$

The patient reported here is affected by an adult-onset mild form of variant $\mathrm{A}-\mathrm{T}$ despite carrying biallelic truncating variants. At the time of the last follow-up visit, she was still ambulatory and there was no evidence for malignant disease by age 45 years.

Such atypically mild clinical expressions may be misleading, and it is not far to seek that single gene testing or narrowly targeted gene panels might significantly prolong the diagnostic odyssey. Nonetheless, our report highlights that even comprehensive genomic approaches may not be sufficient to establish a molecular diagnosis. In our case, ES paved the way for subsequent rephenotyping (confirming telangiectasia) and a more detailed molecular workup (RNA and cDNA sequencing) eventually corroborating disease causation.

We conclude that $\mathrm{A}-\mathrm{T}$ should be taken into consideration as differential diagnosis of adult-onset ataxia, even in the absence of apparent systemic features. The here encountered diagnostic pitfalls support the necessity of a stepwise clinical and molecular reconsideration of genetic testing.

\section{Study funding}

No targeted funding reported.

\section{Disclosure}

Disclosures available: Neurology.org/NG. 


\section{Publication history}

Received by Neurology: Genetics March 14, 2019. Accepted in final form May 23, 2019.

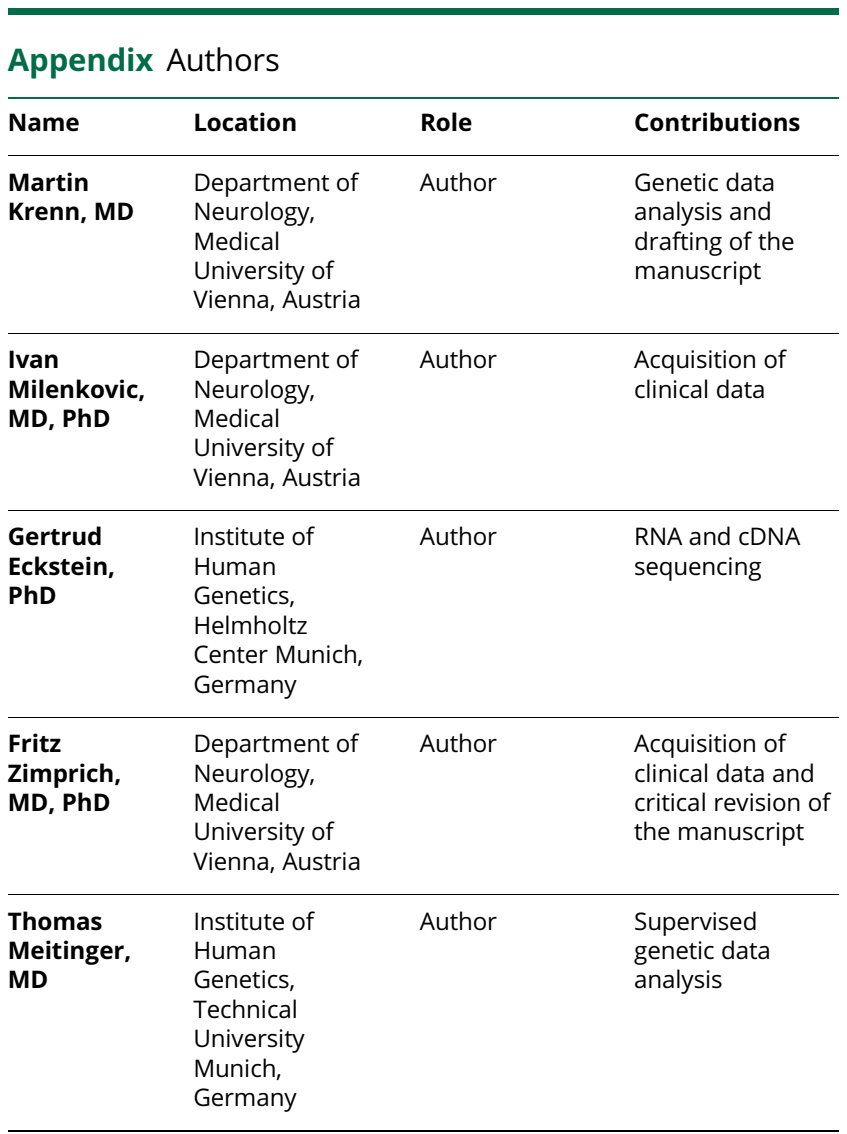

Appendix (continued)

\begin{tabular}{|c|c|c|c|}
\hline Name & Location & Role & Contributions \\
\hline $\begin{array}{l}\text { Thomas } \\
\text { Foki, MD }\end{array}$ & $\begin{array}{l}\text { Karl Landsteiner } \\
\text { University of } \\
\text { Health Sciences, } \\
\text { Tulln, Austria }\end{array}$ & Author & $\begin{array}{l}\text { Major role in data } \\
\text { acquisition and } \\
\text { clinical } \\
\text { management and } \\
\text { critical revision of } \\
\text { the manuscript }\end{array}$ \\
\hline $\begin{array}{l}\text { Matias } \\
\text { Wagner, MD }\end{array}$ & $\begin{array}{l}\text { Institute of } \\
\text { Human } \\
\text { Genetics, } \\
\text { Technical } \\
\text { University } \\
\text { Munich, } \\
\text { Germany }\end{array}$ & $\begin{array}{l}\text { Corresponding } \\
\text { author }\end{array}$ & $\begin{array}{l}\text { RNA and cDNA } \\
\text { sequencing and } \\
\text { proposed and } \\
\text { supervised the } \\
\text { manuscript }\end{array}$ \\
\hline
\end{tabular}

\section{References}

1. Rothblum-Oviatt C, Wright J, Lefton-Greif MA, McGrath-Morrow SA, Crawford TO, Lederman HM. Ataxia telangiectasia: a review. Orphanet J Rare Dis 2016;11:159.

2. Verhagen MMM, Abdo WF, Willemsen MAAP, et al. Clinical spectrum of ataxiatelangiectasia in adulthood. Neurology 2009;73:430-437.

3. Verhagen MMM, Last JI, Hogervorst FBL, et al. Presence of ATM protein and residual kinase activity correlates with the phenotype in ataxia-telangiectasia: a genotype-phenotype study. Hum Mutat 2012;33:561-571.

4. Worth PF, Srinivasan V, Smith A, et al. Very mild presentation in adult with classical cellular phenotype of ataxia telangiectasia. Mov Disord 2013;28: $524-528$.

5. Schon $\mathrm{K}$, van Os NJH, Oscroft $\mathrm{N}$, et al. Genotype, extrapyramidal features, and severity of variant ataxia-telangiectasia. Ann Neurol 2019;85:170-180.

6. Richards S, Aziz N, Bale S, et al. Standards and guidelines for the interpretation of sequence variants: a joint consensus recommendation of the American College of Medical Genetics and Genomics and the Association for Molecular Pathology. Genet Med 2015;17:405-423.

7. Kremer LS, Bader DM, Mertes C, et al. Genetic diagnosis of Mendelian disorders via RNA sequencing. Nat Commun 2017;8:15824. 


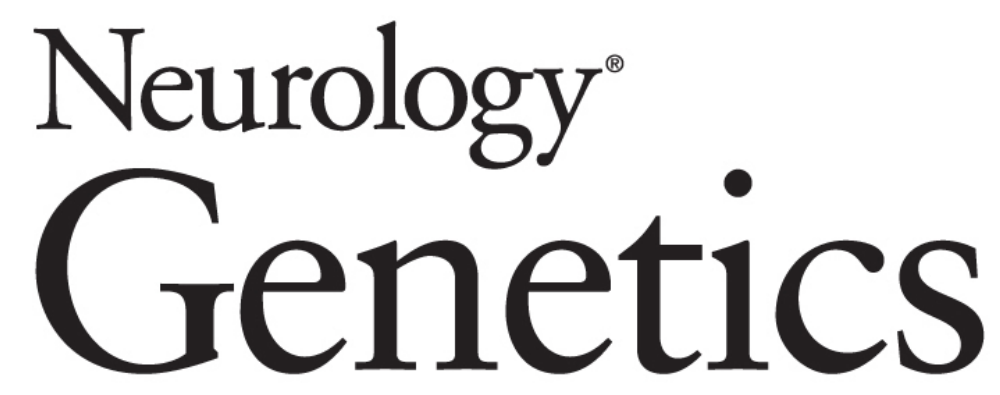

Adult-onset variant ataxia-telangiectasia diagnosed by exome and cDNA sequencing Martin Krenn, Ivan Milenkovic, Gertrud Eckstein, et al. Neurol Genet 2019;5;

DOI 10.1212/NXG.0000000000000346

This information is current as of June 25, 2019

\section{Updated Information \&} Services

References

Subspecialty Collections

Permissions \& Licensing

Reprints including high resolution figures, can be found at: http://ng.neurology.org/content/5/4/e346.full.html

This article cites 7 articles, 0 of which you can access for free at: http://ng.neurology.org/content/5/4/e346.full.html\#\#ref-list-1

This article, along with others on similar topics, appears in the following collection(s):

All Genetics

http://ng.neurology.org//cgi/collection/all_genetics

All Movement Disorders

http://ng.neurology.org//cgi/collection/all_movement_disorders

Gait disorders/ataxia

http://ng.neurology.org//cgi/collection/gait_disorders_ataxia

Information about reproducing this article in parts (figures,tables) or in its entirety can be found online at:

http://ng.neurology.org/misc/about.xhtml\#permissions

Information about ordering reprints can be found online: http://ng.neurology.org/misc/addir.xhtml\#reprintsus

Neurol Genet is an official journal of the American Academy of Neurology. Published since April 2015, it is an open-access, online-only, continuous publication journal. Copyright Copyright @ 2019 The Author(s). Published by Wolters Kluwer Health, Inc. on behalf of the American Academy of Neurology.. All rights reserved. Online ISSN: 2376-7839.

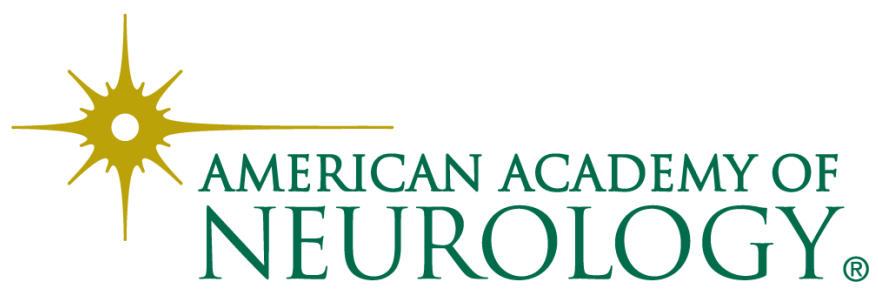

